\title{
Partnerships of Payments for Ecosystem Services on the Watershed Scale
}

\author{
Hebin Lin (Corresponding author) \\ Graduate School of Global Environmental Studies, Kyoto University \\ Yoshida-honmachi, Sakyo-ku, Kyoto 606-8501, Japan \\ Tel: 81-75-753-9167Ｅ-mail: hebin.lin@gmail.com
}

Jeffrey A. Thornton

Environmental Planning Division, Southeastern Wisconsin Regional Planning

Commission

W239 N1812 Rockwood Drive PO Box 1607, Waukesha, Wisconsin 53187-1607, USA

E-mail: jthornton@sewrpc.org

Thomas M. Slawski

Environmental Planning Division, Southeastern Wisconsin Regional Planning

Commission

W239 N1812 Rockwood Drive PO Box 1607, Waukesha, Wisconsin 53187-1607, USA

E-mail: tslawski@sewrpc.org

\author{
Walter Rast \\ International Center for Watershed Studies, Texas State University \\ 601 University Drive, San Marcos, Texas 78666-4616, USA \\ E-mail: walterrast@hotmail.com
}

Received: November 15, 2012 Accepted: December 5, 2012 Published: January 1, 2013 doi:10.5296/ast.v1i1.2891ＵRL: http://dx.doi.org/10.5296/ast.v1i1.2891 


\begin{abstract}
This study discusses some insights for adaptive aquatic ecosystem management, based on evidence of upstream-downstream financial partnerships on watershed scales, or watershed-based Payments for Ecosystem Services (PES) programs. Socioeconomic and watershed information on 13 advanced PES programs being implemented in 13 developing countries was collected and synthesized to analyze their partnership structures. Structured by the distributions of downstream payers and upstream payees within specific legislative tiers and hydrological orders, the PES partnerships revealed three important features with broad implications for aquatic ecosystem management: (1) institutional incentives for water resources, (2) participation units within the watersheds, and (3) organizing scopes for aquatic ecosystem management. In particular, as a reflection of organizing scopes, landscape entrepreneurship, or development of new organizations on the landscape, suggested two visions for adaptive aquatic ecosystem management: (1) connective lifestyles of individual stakeholders, with a transformation from benefiting from ecosystem services to providing conservation services, and (2) compatible technological innovations among organizational stakeholders, with a transformation from supplying latent and disconnected organizing services to strengthening systematic and accountable organizing services. This study is intended to provide a socioeconomic perspective to bridge the domains of water resources management, watershed management, and aquatic ecosystem management, in order to substantially promote diverse scales of stakeholder behavioral adaptations for the common mission of sustainable development in our societies.
\end{abstract}

Keywords: Incentive, Institution, Lifestyle, Partnership, Payments for Ecosystem Services, Technology, Watershed 


\section{Introduction}

At a time of global climate change, societal resources are allocated largely based on the scales of targeted areas (Kollner et al., 2002; Ring, 2002; Hajkowicz, 2007). Subsequently, management of water resources, as in small watersheds and in small aquatic ecosystems, is confronted with poor local adaptation potentials, resulting from less flexible financial resources and vague cooperation regimes. Consequently, it is essential to strengthen the organizational capacities (Ivey et al., 2004) that enable watershed stakeholders to develop mutually re-enforced partnerships for protecting aquatic habitats (Bohn \& Kershner, 2002) to sustain the most fundamental supporting ecosystem services (Millennium Ecosystem Assessment, 2005) of human societies and other biological communities. One promising approach for identifying and overcoming watershed stakeholder challenges in forming financial partnerships is the institutional approach of Payments for Ecosystem Services (PES).

The PES approach suggests that participants can be coordinated (Landell-Mills \& Porras, 2002; Gutman, 2003; Hartmann \& Peterson, 2004; Wunder, 2005; Smith et al., 2006; Leimona et al., 2007; Forest Trends, 2007) to form financial partnerships based on economic incentives through contract transactions (Engel et al., 2008; Ferraro, 2008; Jack et al., 2008) between upstream payees and downstream payers mediated by agreed intermediaries (Figure 1 (a)).

About 163 watershed-based PES programs (Figure 2) have been recognized in 34 developing countries (Lin \& Nakamura, 2012), since the pioneering national PES program was implemented in Costa Rica in 1997 (Chomitz et al., 1998; World Bank, 2006; Pagiola, 2008). However, evaluation of the cost-effectiveness of the PES system and generalization of the PES approach remain two critical policy and research issues. Generalization of the PES approach requires incorporating the economic and institutional ideologies of the PES system within the cultural wisdom and scientific knowledge applicable to various aquatic and terrestrial ecosystems. Importantly, without sufficiently understanding of both the challenges and the potential contributions of the PES approach to managing the socioeconomic, cultural, and scientific inter-linkages of a local human society residing on a landscape, there is very little on which to base answers to the evaluation issue. In other words, it is very limiting to evaluate whether or not the PES approach is more cost-effective than an alternative approach, using traditional evaluation "standards". The main reason is that current or traditional standards do not have a consistent framework within which to examine the institutional principles behind the PES approach, which specifically targets the ecosystem-human interface rather than either side alone. 


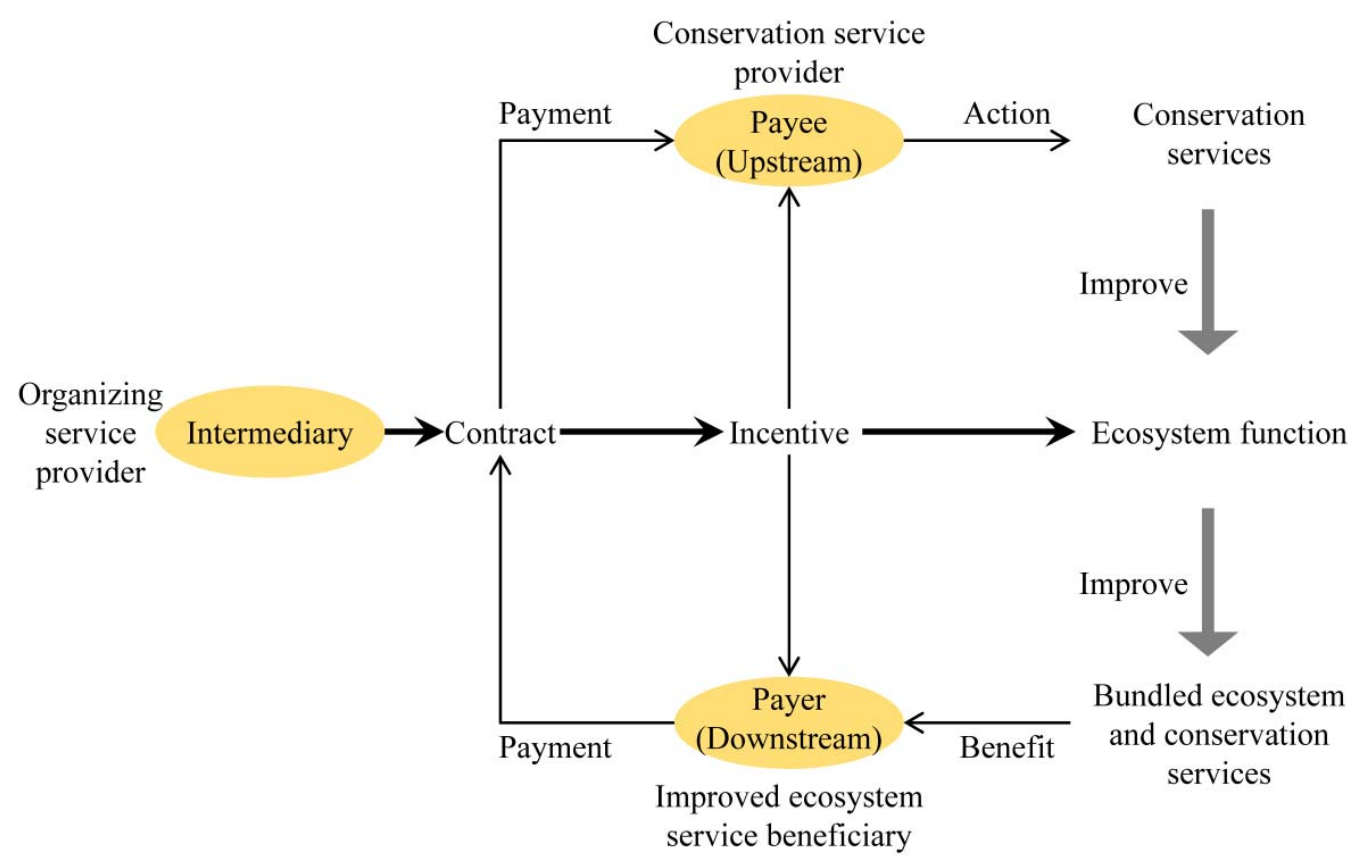

(a)

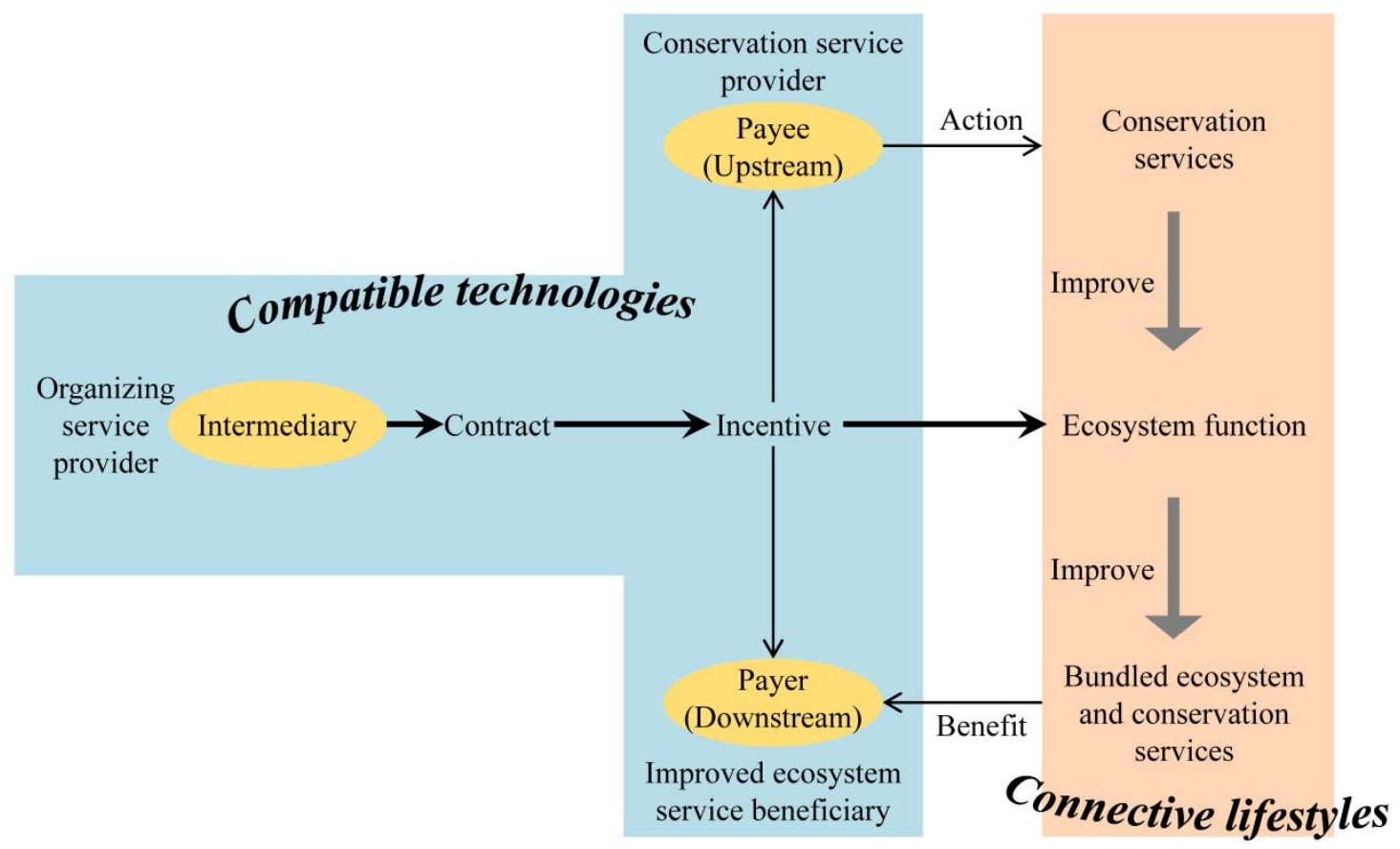

(b)

Figure 1. Watershed-based Payments for Ecosystem Services (PES)

Note: (a) Partnership. (b) Lifestyle adaptation and technological innovation. 
(a) Central America and the Caribbean

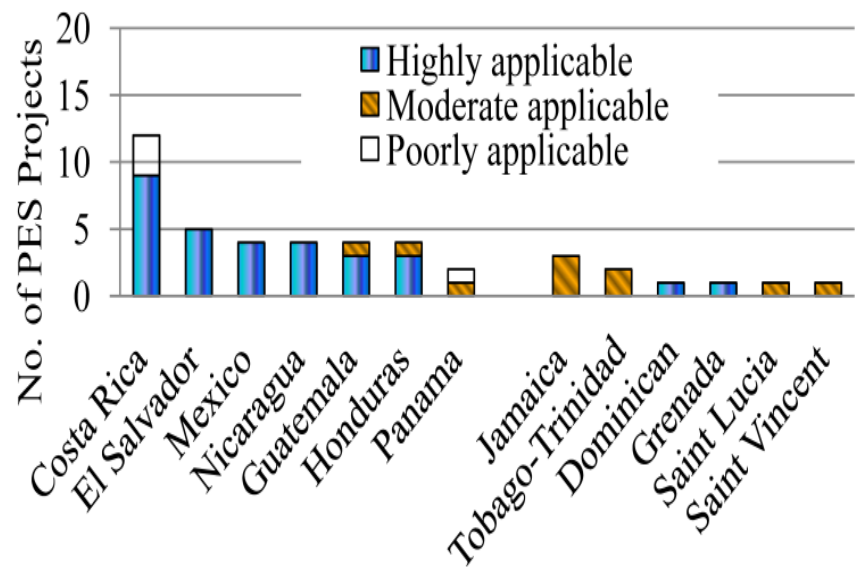

(b) South America

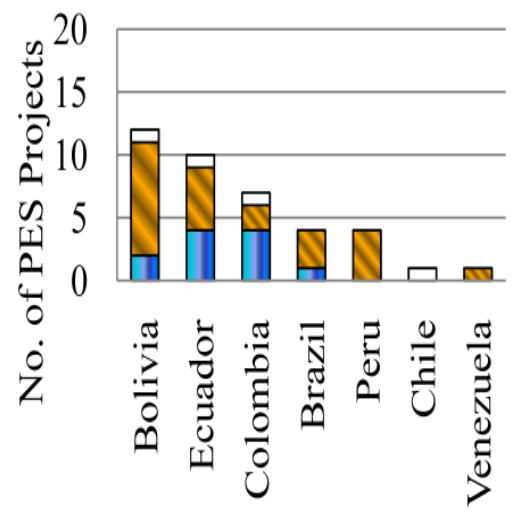

(c) Asia

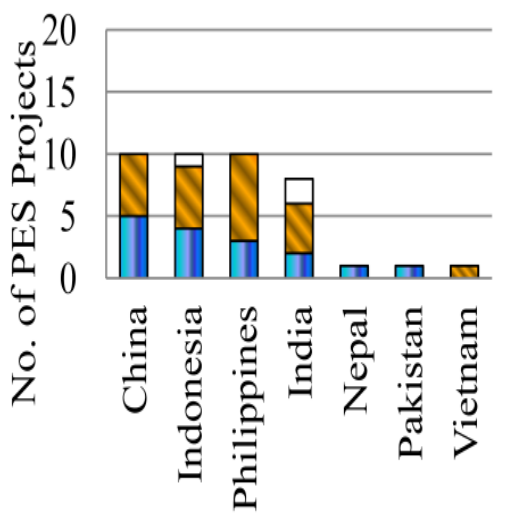

Country (d) Africa

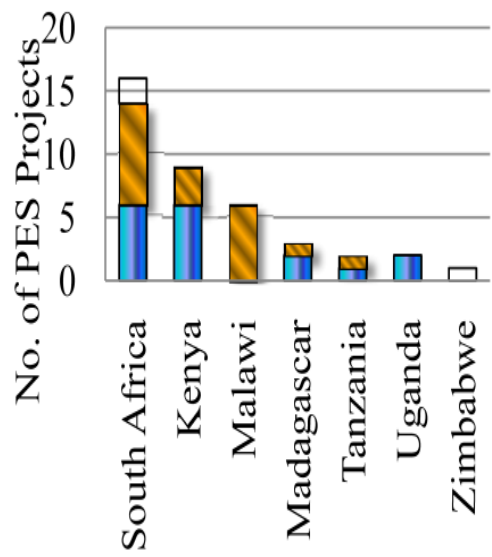

Figure 2. 163 watershed-based Payments for Ecosystem Services (PES) programs proposed in 34 developing countries

Source: Composed based on Table A1 in Lin \& Nakamura, 2012, pp. 203-206.

This paper discusses some insights for adaptive aquatic ecosystem management gleaned from evidence of upstream-downstream financial partnerships on watershed scales, or watershed-based PES programs. It is intended to provide a socioeconomic perspective to bridge the domains of water resources management, watershed management, and aquatic ecosystem management, in order to substantially promote stakeholder behavioral adaptations at diverse scales for the common mission of achieving sustainable development in our societies. In this pursuit, a set of advanced programs suitable for revealing their partnership structures was selected from among the 163 cases and analysed. The features of the PES partnerships with broader implications for aquatic ecosystem management are discussed, and their reflections on understanding the relationships among the three water management domains are explored. 


\section{PES Partnership Structures}

\subsection{Advanced PES Programs}

Of the 163 watershed-based PES programs, 46 programs implemented in 16 countries (Lin \& Ueta, 2012) were relatively well documented. However, most PES literature provided little concrete information regarding the watershed context for the 46 PES programs examined. More specifically, for any given implemented PES program, there was little documentation regarding the geographic, hydrologic, ecological, and legislative scales, in comparison to the institutional backgrounds or institutional environments, to reflect the mechanisms of the implied PES partnerships (exceptions include Miranda et al., 2003; Echavarria et al., 2004; Kosoy et al., 2008).

Against this status, thirteen small-scale PES programs implemented in 13 developing countries were selected from the subset of 46 PES programs and utilized for a detailed examination. The 13 countries included Mexico, Guatemala, El Salvador, Honduras, Nicaragua and Costa Rica in Central America, Colombia, Brazil, Bolivia and Ecuador in South America, and China, Indonesia and India in Asia.

Regarding the institutional arrangements for the 13 PES programs, information from related PES literature was synthesized. The information included: (1) the name of the water body and the year of project initiation, (2) the identity and the names of the organizing intermediaries, (3) the identity of the upstream payees, (4) the conservation services provided by the payees, (5) the identity of the downstream payers, and (6) the ecosystem services demanded by the payers (Appendix 1).

\subsection{Advanced PES Partnerships}

Based on the institutional arrangements, information on the institutional environments of the respective PES programs was also collected, including statistics and studies on the towns, mountains, parks, rivers, lakes, coastal areas, watersheds and landscapes encompassed by the projects. The specific information gathered included:

(1) the townships and the numbers of payees in a transaction year;

(2) the townships and the numbers of payers in a transaction year;

(3) the river systems within the watersheds along which the waterbodies were located;

(4) the legislative and hydrological locations of the payees and payers; and

(5) the hydrological distances in kilometers between the payees and the payers.

Items (1) and (2) represented the participation status in the PES programs (Appendix 2). Items (3), (4) and (5) reflected the partnership structures of the PES programs (Table 1) on the watershed scales. In particular, 4 out of the 13 river-/lake-/reservoir-focused PES programs were located within 154 large watersheds located across the globe (IUCN et al., 2003; Figure 3; Figure 4). 


\section{Ml Macrothink}

Table 1. Partnership structures of 13 advanced, small-scale PES programs

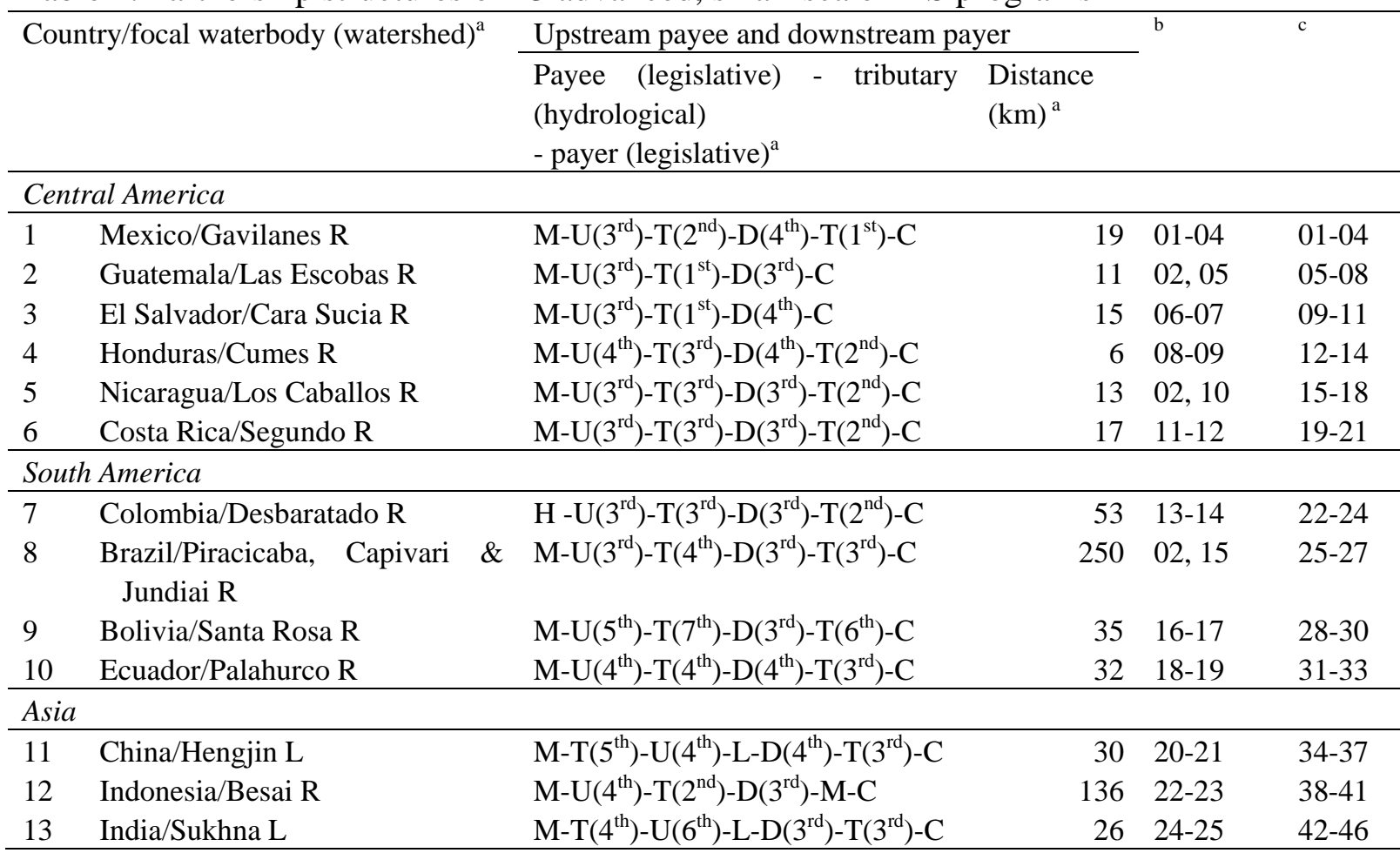

Note: ${ }^{a}$ Distance $(\mathrm{km})$ - distance in kilometers between upstream payees and downstream payers. C - Coast, D downstream, M - Mountain/Hill, L - Lake/Reservoir, R - River, T - tributary, and U - upstream. Numbers in the brackets denote the legislative tiers of the townships in respective countries or the hydrological orders of the tributaries in respective watersheds. 'References for PES institutional arrangements: same as note "cReferences" in Appendix 1. "References for watershed institutional environments: same as note "deferences" in Appendix 2.

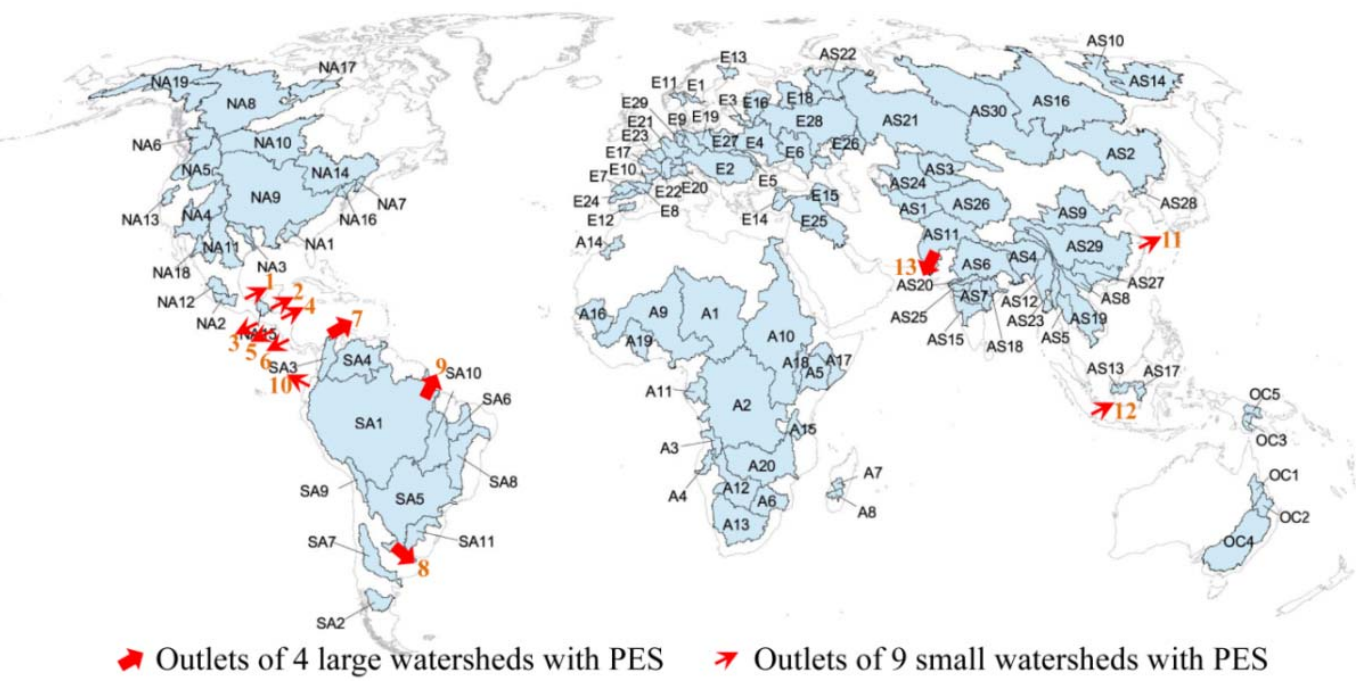

Figure 3. Locations of thirteen advanced, small-scale PES programs among 154 large watersheds and sub-watersheds in the world

Note: NA - North America, SA - South America, E - Europe, A - Africa, AS - Asia, OC - Oceania.

Source: maps are composed based on IUCN et al. 2003, ttp://pdf.wri.org/watersheds_2003/gm1.pdf, with permission granted; the detailed water course of the watersheds are listed in Appendix 1; and other references are listed in Appendix 2. 


\section{Macrothink}
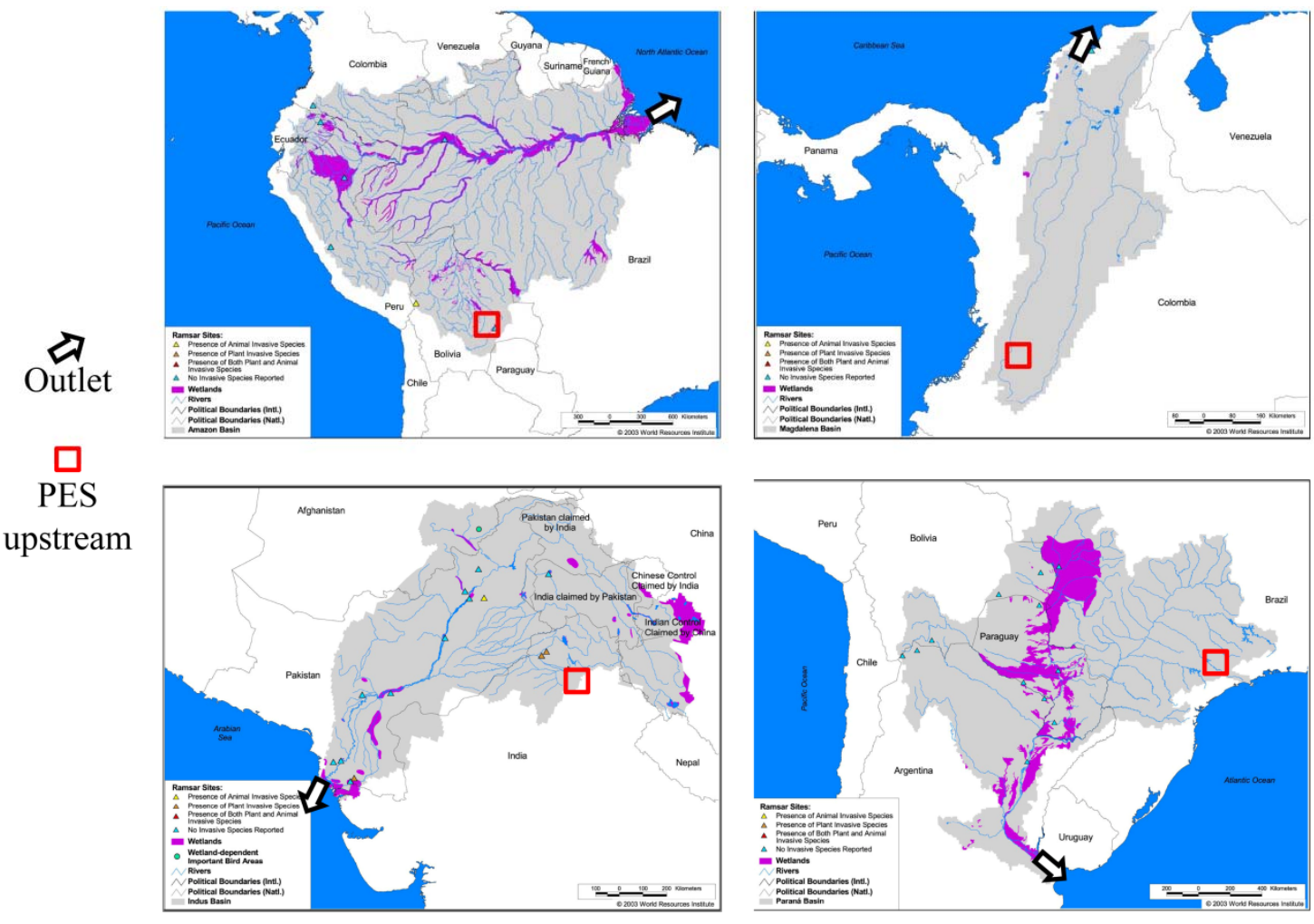

Figure 4. Four advanced, small-scale PES programs in upstream areas of large watersheds Source: Composed based on IUCN et al., 2003, http://pdf.wri.org/watersheds_2003/as12.pdf, http://pdf.wri.org/watersheds_2003/sa13.pdf, http://pdf.wri.org/watersheds_2003/sa1.pdf, http://pdf.wri.org/watersheds_2003/sa15.pdf, with permission granted

\section{Features of PES Partnerships}

Three key features of the PES partnerships examined, useful for aquatic ecosystem management, were: (1) institutional incentives, (2) participation units, and (3) organizing scopes or boundaries.

\subsection{Institutional Incentives for Water Resources Management}

Formed by organizing intermediaries, downstream payers, and upstream payees, the PES partnerships revealed three main institutional incentives (Figure 1 (b)): (1) lifestyle adaptation of upstream payees to provide conservation services (e.g., afforestation instead of deforestation in headwater areas), (2) lifestyle adaptation of downstream payers to recognize the values of bundled conservation and ecosystem services (e.g., water purification through soils), with ecosystem services provided by ecosystem functions (e.g., the inland section of the hydrological cycle), and (3) technological innovation by organizing intermediaries for supporting the lifestyle adaptations on the watershed scale.

\subsection{Participation on Watershed Scales}

The PES partnerships reflected the third legislative tier of a country as a common participation unit for both upstream payees and downstream payers, albeit various legislative 


\section{Macrothink}

distances inbetween (Figure 5). The third legislative tier refers to municipalities in Mexico, Guatemala, El Salvador, Honduras, Nicaragua, Brazil and Indonesia, provinces in Colombia and Ecuador; and, cantons, cities and districts in Costa Rica, China and India, respectively. The legislative distances are counted as the sum of hierarchies from the immediately higher common tier for both the payee and the payer, to the tier of the payee and the tier of the payer. For example, the simplest and the most complicated partnerships were, PES09 (Bolivia) and PES13 (India), respectively. The higher the common tier, the more complicated the PES partnership, since, should a PES contract be breached, a corresponding level of court would be required to determine the expected settlement.

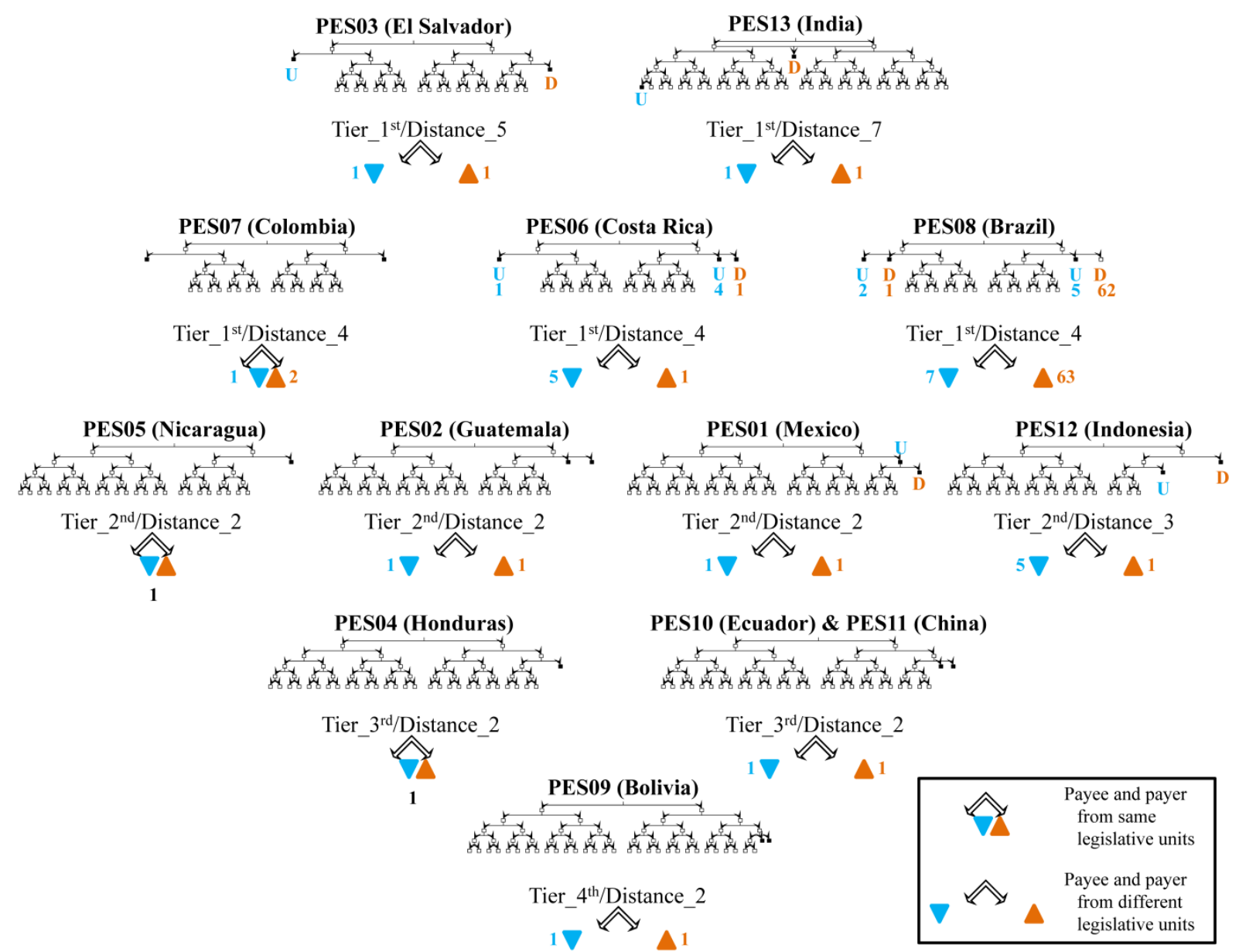

Figure 5. Legislative and hydrological partnership structures of the 13 PES programs Note: D - downstream township, U - upstream township. An empty box denotes a representative legislative unit in the respective legislative tier. A filled box denotes the specific legislative units of PES payees and payers. Structures without $\mathrm{U}$ and $\mathrm{D}$ reflect the symmetric legislative locations of the respective payees and payers.

Three types of PES partnerships, relative to watersheds, also could be distinguished:

- PES partnership type I applied to first (i.e., mainstream) or second hydrological order small rivers as the main water sources to coastal towns located outside of larger watersheds; e.g., 
Coatepec city next to the Papaloapan watershed in Mexico (PES01). Similar cases are PES02 (Guatemala) and PES03 (El Salvador).

- PES partnership type II applied to third or greater hydrological order large rivers as critical water sources for geographical locations of national importance, whether for agriculture, modernization, politics and/or hydrology; e.g., Causa valley in the Magdalena watershed in Columbia (PES07). Similar cases are PES08 (Brazil), PES12 (Indonesia) and PES13 (India).

- PES partnership type III applied to various hydrological order of rivers to downstream towns experiencing acute water quantity reduction and/or water quality deterioration, the status of which could be directly improved by land users immediately $(<40 \mathrm{~km}$ ) upstream; e.g., farmers in Honduras (PES04), Nicaragua (PES05), Costa Rica (PES06) and Ecuador (PES10), foresters in Bolivia (PES09), and urban residents in China (PES11).

\subsection{Organizing Scopes for Aquatic Ecosystems}

Since the upstream and downstream PES participants were not constrained to specific legislative or hydrological units, the PES partnerships indicated the organizing scopes of the PES programs as being superior to both the legislative and the hydrological boundaries. Such a feature has direct and significant implications for the coordination difficulties induced by the inconsistency between legislative, hydrological and socioeconomic boundaries in integrated water resources management. In particular, reconciling these difficulties suggests that, for PES programs to succeed, organizing scopes at the entrepreneurship level would be required to discover opportunities to transform social demands into social values.

The behavioral perspective (Gartner, 1988; Thornton, 1999) of entrepreneurship emphasizes the greater benefit of promoting “entrepreneurship” (i.e., creation of new organizations) over defining "entrepreneurs" (i.e., founders of new organizations). Indeed, the PES programs all reflected the importance of partnerships not only in the form of spatial cooperation at a specific temporal point, but also in defining a vision for developing new organizations to improve long-term ecosystem management. Such a vision is particularly crucial for aquatic ecosystem management since it is the domain that connects both water resources management and watershed management, which in turn underpins the healthy and sustainable development of every human society at any location on our planet.

Two visions can be reflected by the PES partnership features to define the relationships between entrepreneurship and aquatic ecosystem management:

- Vision 1: connective lifestyles for individual stakeholders (e.g., urban and rural citizens) residing in watersheds, with a transformation from benefiting from ecosystem services to providing conservation services; and

- Vision 2: compatible technological innovation for organizational stakeholders (e.g., municipal governments and manufactures) acting on landscapes, with a transformation from supplying latent and disconnected organizing services to strengthening systematic and accountable organizing services.

Aside from partnerships and entrepreneurships for adaptive aquatic ecosystem management 
on the watershed scale, the connectivity between individuals, the compatibility of technologies, and the necessary institutional changes from the individual level to the organizational level, reflect the following important and interrelated institutional aspects:

- Organizing services infrastructure similar to but more broadly based than that of existing public service infrastructure; e.g., water, electricity, transportation and communication (OECD, 2010);

- Social capital, i.e., networks, shared norms, and trust (Putnam, 1995); and

- Interactive governance, i.e., interactions taken to solve societal problems and to create societal opportunities (Kooiman et al., 2005).

\section{Discussions and Conclusion}

The three key features of the PES partnerships reflected from the 13 advanced, small-scale PES programs collectively suggest the needs and prospects for developing an integrated water governance system to connect the three thus far detached water management dimensions - water resources management, watershed management and aquatic ecosystem management. One prospect of generalizing the PES partnership rationales resides on the fact that the PES organizing boundaries can take precedence over both legislative boundaries and hydrological tiers. Indeed, the analysis in this study has demonstrated that upstream and downstream participants in PES programs were not constrained to specific legislative or hydrological boundaries. Rather, they belonged to legislative units of same, different or mixed legislative tiers, ranging from the $3^{\text {rd }}$ to the $6^{\text {th }}$ tiers of government; they resided in watershed sections confined between different hydrological orders, ranging from the $1^{\text {st }}$ order (i.e., mainstream) to $7^{\text {th }}$ order tributaries within the watersheds. On the other hand, one significant challenge for such prospect would be a sound theoretical framework to integrate the governance aspects of institutional incentives, participation units and organizing scopes, and of more fundamental socioeconomic issues such as transaction costs and property rights. Without such a theoretical framework, the important institutional aspects of partnerships, entrepreneurships, organizing services infrastructure, social capital, and their interrelated roles in a governance system could not be effectively incorporated with current aquatic management systems. Similarly, nor could these aspects be effectively incorporated to reflect the necessary interactions between managing aquatic ecosystems and managing terrestrial ecosystems. An explorative analysis will be given in another publication (Lin \& Thornton 2013). Subsequent topics for investigation arising from this line of reasoning could provide a wider horizon for promoting new management philosophies for both lifestyle adaptation and technological innovation. As such, we invite various professionals and kindred spirits to join in the glorious exploration of realizing a dream that has been long imagined, a vision which would be called by many as sustainable development of human societies in the adaptive, vivacious and invaluable Earth ecosystem.

\section{Acknowledgement}

The authors are very grateful for the constructive comments on the previous drafts by the two anonymous reviewers. This study benefitted from the field trip (November 2009) conducted 
by the Field Science Education and Research Center (FSERC) in Kyoto University for the research project "Public Policy and Dam Construction in Toyo River, Aichi Prefecture, Japan”, and from discussions (May 2010 - January 2011) within the International Lake Environment Committee (ILEC) working group preparing the "Methodology for the GEF Transboundary Waters Assessment Programme: Methodology for the Assessment of Transboundary Lake Basins”. The opinions presented herein are those of the authors and do not necessarily reflect the opinions of FSERC or ILEC.

\section{References}

Agarwal, A., \& Narain, S. (2010). Equitable sharing of benefits in Sukhomajri India. [Online] Available: http://www.eea.europa.eu/atlas/teeb/equitable-sharing-of-benefits-in/view/view. (Nov 15, 2012).

Arifin, B. (2006). Transaction cost analysis of upstream-downstream relations in watershed services: lessons from community based forestry management in Sumatra, Indonesia. Quarterly Journal of International Agriculture, 45, 361-375.

Asquith, N. M., Vargas, M. T., \& Wunder, S. (2008). Selling two environmental services: in-kind payments for bird habitat and watershed protection in Los Negros, Bolivia. Ecological Economics, 65(4), 675-684. http://dx.doi.org/10.1016/j.ecolecon.2007.12.014

Barrantes, G., \& Gamez, L. (2007). Programa de Pago por Servicio Ambiental Hídrico de la Empresa de Servicios Publicos de Heredia. Paper prepared for Ecomarkets: Costa Rica's Experience with Payments for Environmental Services. [Online] Available: http://siteresources.worldbank.org/INTEEI/Resources/CostaRica-14-Heredia.pdf. (Nov 15, 2012). Spanish.

Blanco, R., \& Rojo, P. (2005). Fideicomiso para el pago de servicios ambientales forestales Coatepec, Veracruz. [Online] Available: http://www.premiomunicipal.org.mx/p2009/pa_descargar_doc.php?idRegistro=4604\&tipo=p df. (Nov 15, 2012). Spanish.

Board of Regents. (1975). Atlas of Mexico. Austin (TX): The University of Texas System. [Online] Available: http://www.lib.utexas.edu/maps/atlas_mexico/index.html. (Nov 15, 2012).

Bohn, B. A., \& Kershner, J. L. (2002). Establishing aquatic restoration priorities using a watershed approach. Journal of Environmental Management, 64, 355-363. http://dx.doi.org/10.1006/jema.2001.0496

Bolivia Institute of Military Geography (Instituto Geografico Militar). (2012). Mapa Hidrografico de Bolivia. [Online] Available: http://www.mirabolivia.com/mapa_muestra.php?id_mapa=128. (Nov 15, 2012). Bolivia Institute of Military Geography (Bolivia IGM). Spanish.

Bolivia National Institute of Statistics (Instituto Nacional de Estadistica de Bolivia). (2010). Demographic $\quad$ statistics $2010 . \quad$ [Online] Available: http://www.ine.gob.bo/indice/visualizador.aspx?ah=PC20407.HTM. (Nov 15, 2012). Bolivia 
National Institute of Statistics (Bolivia INE). Spanish.

Brazil Institute of Geography and Statistics (Instituto Brasileiro de Geografia e Estatistica). (2010). Censo Demografico 2010. [Online] Available: http://www.ibge.gov.br/home/mapa_site/mapa_site.php\#populacao. (Nov 15, 2012). Brazil Institute of Geography and Statistics (Brazil IBGE). Portuguese.

Castellon, R. D., Nunez, G. C., \& Aceves, A. A. (2008). Mechanical instability quantification of slopes at Cofre de Perote volcano, eastern Mexico. Boletin de la Sociedad Geolgica Mexicana, 60(2), 187-201.

China Committee for International Cooperation on Environment and Development. (2006). Eco-compensation mechanisms and policies in China. [Online] Available: http://www.caep.org.cn/english/paper/CCICED-TF-Summary-Report-on-Eco-compensationPolicy-in-China.pdf. (Nov 15, 2012). China Committee for International Cooperation on Environment and Development (CCICED).

China National Bureau of Statistics. (2003). The fifth population census (2000) by county. [Online] Available: http://www.stats.gov.cn/tjsj/ndsj/renkoupucha/2000fenxian/htm/table1.htm. (Nov 15, 2012). China National Bureau of Statistics (China NBS). Chinese.

Chomitz, K. M., Brenes, E., \& Constantino, L. (1998). Financing environmental services: the Costa Rican experience. Washington, DC: World Bank.

Colombia National Administrative Department of Statistics (Departamento Administrativo Nacional de Estadistica). (2005). Demographic statistics 2005. [Online] Available: http://www.dane.gov.co/index.php?option=com_content\&view=article\&id=75\&Itemid=72.

(Nov 15, 2012). Colombia National Administrative Department of Statistics (Colombia DANE). Spanish.

Corbera, E., Kosoy, N., \& Tuna, M. M. (2007). Equity implications of marketing ecosystem services in protected areas and rural communities: Case studies from Meso-America. Global Environmental Change, 17(3-4), 365-380. http://dx.doi.org/10.1016/j.gloenvcha.2006.12.005

Costa Rica Institute for Municipal Development and Advisory Services (Instituto de Fomento y Asesoria Municipal). (1985). Atlas Cantonal de Costa Rica. [Online] Available: http://ns.ccp.ucr.ac.cr/bvp/mapoteca/CostaRica/generales/atlas_cantonal_1984/. (Nov 15, 2012). Costa Rica Institute for Municipal Development and Advisory Services (Costa Rica IFAM). Spanish.

Costa Rica National Institute of Statistics (Instituto Nacional de Estadistica y Censos de Costa Rica). (2011). Censo 2011. [Online] Available: http://www.inec.go.cr/Web/Home/GeneradorPagina.aspx. (Nov 15, 2012). Costa Rica National Institute of Statistics (Costa Rica INEC). Spanish.

Da Silva, R. T., \& Folegatti, M. V. (2009). Raw water use charge reduction for the rural sector in the PCJ Watershed. Engenharia Agricola, 29(3), 492-500. http://dx.doi.org/10.1590/S0100-69162009000300016 
Del Angel-Perez, A. L., Daaz-Padilla, G., Guajardo-Panez, R., \& Linares-Bravo, B. C. (2011). Landscapes and fragile economy: ecosystems and agroecosystems in the Coatepec - La Antigua basin, Veracruz, Mexico. Tropical and Subtropical Agroecosystems, 14(2), 629-642.

Echavarria, M. (2002). Water user associations in the Cauca Valley, Colombia: a voluntary mechanism to promote upstream-downstream cooperation in the protection of rural watersheds. Rome, Italy: Food and Agriculture Organization (FAO).

Echavarria, M., Vogel, J., Alban, M., \& Meneses, F. (2004). The impacts of payments for watershed services in Ecuador: emerging lessons from Pimampiro and Cuenca. London, England: International Institute for Environment and Development (IIED).

Ecuador National Institute of Statistics and Census (Instituto Nacional de Estadistica y Censos de Ecuador). (2010). Demographic statistics 2010. [Online] Available: http:/www.inec.gob.ec/cpv/index.php?option=com_content\&view=article\&id=222\&Itemid= 66\&lang=es. (Nov 15, 2012). Ecuador National Institute of Statistics and Census (Ecuador INEC). Spanish.

El Salvador Ministry of Economy (Ministerio de Economia de El Salvador). (2009). Estimactiones y Proyecciones Municipales de Poblacion 2005 - 2020. [Online] Available: http://www.digestyc.gob.sv/index.php/temas/des/poblacion-y-estadisticas-demograficas/cens o-de-poblacion-y-vivienda/publicaciones-censos.html. (Nov 15, 2012). El Salvador Ministry of Economy (El Salvador MINEC). Spanish.

Engel, S., Pagiola, S., \& Wunder, S. (2008). Designing payments for environmental services in theory and practice: an overview of the issues. Ecological Economics, 65(4), 663-674. http://dx.doi.org/10.1016/j.ecolecon.2008.03.011

Fang, X., Zhang, J., Chen, Y., \& Xu, X. (2008). QUAL2K model used in the water quality assessment of Qiantang River, China. Water Environment Research, 80(11), 2125-2133. http://dx.doi.org/10.2175/106143008X304794

Ferraro, P. J. (2008). Asymmetric information and contract design for payments for environmental services. Ecological Economics, 65(4), 810-821. http://dx.doi.org/10.1016/j.ecolecon.2007.07.029

Forest Trends. (2007). Getting started: an introductory primer to assessing \& developing payments for ecosystem service deals. Washington, DC: Forest Trends.

Formiga-Johnsson, R. M., Kumler, L., \& Lemos, M. C. (2007). The politics of bulk water pricing in Brazil: lessons from the Paraiba do Sul River Basin. Water Policy, 9(1), 87-104. http://dx.doi.org/10.2166/wp.2006.001

Gartner, W. B. (1988). “Who is an entrepreneur?” is the wrong question. Entrepreneurship Theory and Practice, 13(4), 47-68.

Greiber, T. (2009). Payments for ecosystem services: legal and institutional frameworks. Gland, Switzerland: World Conservation Union (IUCN). 
Guatemala National Institute of Statistics (Instituto Nacional de Estadistica de Guatemala). (2002). Guatemala: Estimaciones de la poblacion total por municipio 2002. [Online] Available: http://www.ine.gob.gt/np/poblacion/index.htm. (Nov 15, 2012). Guatemala National Institute of Statistics (Guatemala INE). Spanish.

Gutman, P. (2003). From goodwill to payments for environmental services: a survey of financing options for sustainable natural resource management in developing countries. Gland, Switzerland: World Wide Fund for Nature (WWF).

Hajkowicz, S. (2007). Allocating scarce financial resources across regions for environmental management in Queensland, Australia. Ecological Economics, 61(2), 208-216. http://dx.doi.org/10.1016/j.ecolecon.2006.10.011

Hartmann, J., \& Peterson, L. (2004). “Marketing” environmental services: lessons learned in German development cooperation. [Online] Available: http://www.infoandina.org/system/files/recursos/marketing_PSA.pdf. (Nov 15, 2012).

Herrador, D., \& Dimas, L. (2000). Payment for environmental services in El Salvador. Mountain Research and Development, 20(4), 306-309. http://dx.doi.org/10.1659/0276-4741(2000)020[0306:PFESIE]2.0.CO;2

Herzog, S. K., Hennessey, A. B., Kessler, M., \& Garciasoliz, V. H. (2008). Distribution, natural history and conservation status of two endemics of the Bolivian Yungas, Bolivian Recurvebill Simoxenops striatus and Yungas Antwren Myrmotherula grisea. Bird Conservation International, 18(4), 331-348. http://dx.doi.org/10.1017/S0959270908007491

Honduras National Institute of Statistics (Instituto Nacional de Estadistica de Honduras). (2006). Honduras: Proyecciones de Poblacion 2001-2050. Tegucigalpa: Honduras INE. Honduras National Institute of Statistics (Honduras INE). Spanish.

India Ministry of Water Resources. (2007). Ground water information booklet of Chandigarh (U.T.). Chandigarh, India. [Online] Available: http://cgwb.gov.in/District_Profile/Chandigarh/CHANDIGARH.pdf. (Nov 15, 2012). India Ministry of Water Resources (India MWR).

India Office of Registrar General \& Census Commissioner. (2011). Census of India 2011. [Online] Available: http://www.censusindia.gov.in/. (Nov 15, 2012). India Office of Registrar General \& Census Commissioner (India Census).

Indonesia Ministry of Public Works (Kementerian Pekerjaan Umum Republic Indonesia). [Online] Available: http://www.pu.go.id. (Nov 15, 2012). Indonesia Ministry of Public Works (Indonesia KPU).

Indonesia National Institute of Statistics (Badan Pusat Statistik). (2010). Population of Indonesia by village. Result of 2010 population census. [Online] Available: http://dds2.bps.go.id/eng/menutab.php?tabel=1\&kat=1\&id_subyek=12. (Nov 15, 2012). Indonesia, National Institute of Statistics (Indonesia BPS).

IUCN, International Water Management Institute, Ramsar Convention Bureau and World Resources Institute. (2003). Water resources eAtlas. [Online] Available: http://www.wri.org/publication/watersheds-of-the-world. (Nov 15, 2012). 
Ivey, J. L., Smithers, J., de Loe, R. C., \& Kreutzwiser, R. D. (2004). Community capacity for adaptation to climate-induced water shortages: linking institutional complexity and local $\begin{array}{llll}\text { actors. } & \text { Environmental 36nagement, }\end{array}$ http://dx.doi.org/10.1007/s00267-003-0014-5

Jack, B. K., Kousky, C., \& Sims, K. R. E. (2008). Designing payments for ecosystem services: lessons from previous experience with incentive-based mechanisms. Proceedings of the National Academies of Sciences of the United States of America, 105(28), 9465-9470. http://dx.doi.org/10.1073/pnas.0705503104

Kelly, E. P. (2009). An assessment of the potential for developing ecotourism in the San Francisco Menendez sector of El Imposible National Park, El Salvador. (M. Sc. Thesis). University of Alaska Fairbanks, Fairbanks, AL.

Kocsis, J. L. (2011). Extreme weather, climate change and the livelihoods of hillside households in the Jesus De Otoro Valley, Honduras. (M. Sc. Thesis). The University of Guelph, Guelph, Canada.

Kollner, T., Schelske, O., \& Seidl, I. (2002). Integrating biodiversity into intergovernmental fiscal transfers based on cantonal benchmarking: a Swiss case study. Basic and Applied Ecology, 3(4), 381-391. http://dx.doi.org/10.1078/1439-1791-00104

Kooiman, J., Bavinck, M., Jentoft, S., \& Pullin, R. (2005) Fish for life. Amsterdam, the Netherlands: Amsterdam University Press.

Kosoy, N., Corbera, E., \& Brown, K. (2008). Participation in payments for ecosystem services: case studies from the Lacandon rainforest, Mexico. Geoforum, 39(6), 2073-2083. http://dx.doi.org/10.1016/j.geoforum.2008.08.007

Kosoy, N., Martinez-Tuna, M., Muradian, R., \& Martinez-Alier, J. (2007). Payments for environmental services in watersheds: insights from a comparative study of three cases in Central Americar Ecological Economics, 61(2-3), 446-455. http://dx.doi.org/10.1016/j.ecolecon.2006.03.016

Landell-Mills, N., \& Porras, I. (2002). Silver bullet or fool's gold? A global review of markets for forest environmental services and their impacts on the poor. London, England: IIED.

Lawler, A. (2011). In Indus times, the river didn't run through it. Science, 332(6025), 23. http://dx.doi.org/10.1126/science.332.6025.23

Leimona, B., Villamor, G., van Noordwijk, M., Fauzi, A., \& Utaira, R. (2007). Developing mechanisms to reward the upland poor in Asia for environmental services that they provide (RUPES). Bogor, Indonesia: World Agroforestry Centre (ICRAF).

Lin, H., \& Nakamura, M. (2012). Payments for watershed services: directing incentives for improving lake basin governance. Lakes \& Reservoirs: Research and Management, 17(3), 191-206. http://dx.doi.org/10.1111//re.12004

Lin, H., \& Thornton, J. A. (2013). Integrated payments for ecosystem services: a 
governance path from lakes and rivers to coastal areas in China. In Mohammed, E. Y. (Ed.), Payments for Coastal and Marine Ecosystem Services: Prospects, Challenges and Policy Implications. London, England: Earthscan. Forthcoming.

Lin, H., \& Ueta, K. (2012). Lake watershed management: services, monitoring, funding and governance. Lakes \& Reservoirs: Research and Management, 17(3), 207-223. http://dx.doi.org/10.1111//re.12003

Liu, J., Li, A., Xu, K., Velozzi, D., Yang, Z., Milliman, J. D., \& DeMaster, D. J. (2006). Sedimentary features of the Yangtze River-derived along-shelf clinoform deposit in the East China Sea. Continental Shelf Research, 26(17-18), 2141-2156. http://dx.doi.org/10.1016/j.csr.2006.07.013

Manik, T. K. (2008). Hydrological consequences of converting forestland to coffee plantations and other agriculture crops on Sumber Jaya watershed, West Lampung, Indonesia. (Ph.D dissertation). National University of Singapore, Singapore.

Mastin, M. C. (2002). Flood-hazard mapping in Honduras in response to hurricane Mitch. Water-Resources Investigations Report 01-4277. Washington, DC: U.S. Geological Survey.

Mexico National Institute of Statistics and Geography (Instituto Nacional de Estadistica y Geografia). (2011). Anuario Estadistico 2011. Mexico, Mexico: Tallers Graficos del Instituto Nacional de Estadistica, Geografia e Informatica. [Online] Available: http://www.veracruz.gob.mx/finanzas/anuario-estadistico-2011/. (Nov 15, 2012). Mexico National Institute of Statistics and Geography (Mexico INEGI). Spanish.

Millennium Ecosystem Assessment. (2005). Ecosystems and Human Well-being: Current State and Trends (Vol. 1). Washington, DC: Island Press.

Miranda, M., Porras, I. T., \& Moreno, M. L. (2003). The social impacts of payments for environmental services in Costa Rica: a quantitative field survey and analysis of the Virilla watershed. London, England: IIED.

Nicaragua Institute for Earth Studies (Instituto Nicarauense de Estudios Territoriales). (2012). Mapas departamentales. Chinandega. [Online] Available: http://www.ineter.gob.ni/images/stories/mapas/tematicos/geodesia/departamentales/chinande ga.jpg. (Nov 15, 2012). Nicaragua Institute for Earth Studies (Nicaragua INETER). Spanish. Nicaragua National Institute of Information and Development (Instituto Nacional de Informacion de Desarrollo de Nicaragua). (2009). Anuario Estadistico National 2008. [Online] Available: http://www.inide.gob.ni/. (Nov 15, 2012). Nicaragua National Institute of Information and Development (Nicaragua INIDE). Spanish.

Organisation for Economic Co-operation and Development. (2010). Pricing water resources and water and sanitation services. Paris, France: Organisation for Economic Co-operation and Development (OECD).

Pagiola, S. (2008). Payments for environmental services in Costa Rica. Ecological Economics, 65(4), 712-724. http://dx.doi.org/10.1016/j.ecolecon.2007.07.033 
Pasha, R., \& Leimona, B. (2011). PES and multi-strata coffee gardens in Sumberjaya, Indonesia. In FAO, Payments for ecosystem services and food security (pp. 274-281). Rome, Italy: FAO.

Perez, C. J., Vignola, R., \& Perez, H. (2007). Community based adaptation to climate variability and change in agriculture and water resources in the dry tropics of Nicaragua: the case of San Pedro del Norte. [Online] Available: http://www.docstoc.com/docs/50533024/Community-based-adaptation-to-climate-variabilityand-change-in. (Nov 15, 2012).

Porras, I. T., \& Neves, N. (2006). Markets for watershed services - country profiles. [Online] Available: http://www.watershedmarkets.org/index.html. (Nov 15, 2012).

Putnam, R. D. (1995). Tuning in, tuning out: the strange disappearance of social capital in America. PS: Political Science \& Politics, 28(4), 664-683. http://dx.doi.org/10.2307/420517

Restrepo, J. D., Zapata, P., Diaz, J. M., Garzon-Ferreira, J., \& Garcia, C. B. (2006). Fluvial fluxes into the Caribbean Sea and their impact on coastal. Global Planetary Change, 50(1-2), 33-49. http://dx.doi.org/10.1016/j.gloplacha.2005.09.002

Ring, I. (2002). Ecological public functions and fiscal equalisation at the local level in Germany. Ecological Economics, 42(3), 415-427. http://dx.doi.org/10.1016/S0921-8009(02)00124-6

Rojas, M., \& Aylward, B. (2003). What are we learning from experiences with markets for environmental services in Costa Rica? London, England: IIED.

Rosa, H., Kandel, S., \& Dimas, L. (2003). Compensation for environmental services and rural communities: Lessons from the Americas and key issues for strengthening community strategies. San Salvador: The Salvadoran Research Program on Development and Environment (PRISMA). [Online] Available: http://www.cbd.int/doc/case-studies/inc/cs-inc-prisma-en-01.pdf. (Nov 15, 2012).

Scullion, J., Thomas, C. W., Vogt, K. Z., Perez-Maqueo, O., \& Logsdon, M. G. (2011). Evaluating the environmental impact of payments for ecosystem services in Coatepec (Mexico) using remote sensing and on-site interviews. Environmental Conservation, 38(4), 426-434. http://dx.doi.org/10.1017/S037689291100052X

Sengupta, S., Mitra, K., Saigal, S., Gupta, R., Tiwari, S., \& Peters, N. (2003). Developing markets for watershed protection services and improved livelihoods in India. Unpublished draft. Winrock International India, New Delhi and IIED. [Online] Available: http://pubs.iied.org/pdfs/G00399.pdf. (Nov 15, 2012).

Singh, V., \& Tandon, S. K. (2008). The Pinjaur dun (intermontane longitudinal valley) and associated active mountain fronts, NW Himalaya: tectonic geomorphology and morphotectonic evolution. Geomorphology, 102(3-4), 376-394. http://dx.doi.org/10.1016/j.geomorph.2008.04.008

Singh, Y. (2002). Siltation problems in Sukhna Lake in Chandigarh, NW India and comments 
on geohydrogical changes in the Yamuna-satluj region. Envis Bull.: Himalayan Ecology and Development, 10(2), 18-31.

Smith, M., de Groot, D., Perrot-Maite, D., \& Bergkamp, G. (2006). Pay - establishing payments for watershed services. Gland, Switzerland: IUCN. http://dx.doi.org/10.2305/IUCN.CH.2006.WANI.4.en

Suyanto, S., Khususiyah, N., \& Leimona, B. (2007). Poverty and environmental services: case study in Way Besai watershed, Lampung Province, Indonesia. Ecology and Society, 12(2), 13-26.

Thaittai, D., Kjerfve, B., \& Heyman, W. D. (2003). Hydrometeorology and variability of water discharge and sediment load in the inner Gulf of Honduras, Western Caribbean. Journal of Hydrometeorology, 4(6), 985-995. http://dx.doi.org/10.1175/1525-7541(2003)004<0985:HAVOWD>2.0.CO;2

Thornton, P. H. (1999). The sociology of entrepreneurship. Annual Review of Sociology, 25(1), 19-46. http://dx.doi.org/10.1146/annurev.soc.25.1.19

United Nations Environmental Programme. (2005). Plan de manejo integrado microcuenca del Rio Las Escobas, Izabal, Guatemala. proyecto "Planificacion de la rehabilitacion, manejo ambiental y desarrollo costero en Nicaragua, Honduras y Guatemala despues del Huracan Mitch”. [Online] Available: http://www.cep.unep.org/pubs/meetingreports/LBS\%20ISTAC\%20III/spanish/PM\%20Guate mala.pdf. (Nov 15, 2012). United Nations Environmental Programme (UNEP). Spanish.

US Army Corps of Engineers. (1998a). Water resources assessment of Ecuador. [Online] Available: Www.sam.usace.army.mil/en/wra/Ecuador/Ecuador\%20WRA\%20English.pdf. (Nov 15, 2012). US Army Corps of Engineers (USACE).

US Army Corps of Engineers. (1998b). Water resources assessment of El Salvador. [Online] Available:

www.sam.usace.army.mil/en/wra/ElSalvador/El\%20Salvador\%20WRA\%20English.pdf.

(Nov 15, 2012).

Vargas, M. T. (2004). Evaluating the economic basis for payments-for-watershed-services around Amboro National Park, Bolivia. (M. Sc. Thesis). Yale University, New Haven, NY.

Weller Cartographic Services. (1998). Nicaragua. [Online] Available: http://www.mapmatrix.com/tmhtm/mapcat.html\#Anchor-South-35882. (Nov 15, 2012). Weller Cartographic Services (WCS).

World Bank. (2004). Decentralization of rural water and sanitation services: new roles for rural water associations and boards in Honduras. UNDP - Water and Sanitation Program; field note. Washington, DC: World Bank.

World Bank. (2006). Scaling up and mainstreaming payment for environmental services in Costa Rica. Washington, DC: World Bank.

World Bank. (2011). Mexico - environmental services project. Implementation completion 
and results report. Report No: ICR00002161. Washington, DC: World Bank.

Wunder, S. (2005). Payments for environmental services: some nuts and bolts. Bogor, Indonesia: Center for International Forestry Research (CIFOR).

Wunder, S. (2011). PES for improved ecosystem water services in Pimampiro town, Ecuador. In FAO, Payments for ecosystem services and food security (pp. 156-161). Rome, Italy: FAO.

Yanez-Arancibia, A., Lomeli, D. Z., Cruz, M. G., Orantes, R. G. \& Frandino, V. S. (1999). The ecosystem framework for planning and management the Atlantic coast of Guatemala. $\begin{array}{llll}\text { Ocean } \quad \& \quad \text { Coastal } & \text { Management, }\end{array}$ http://dx.doi.org/10.1016/S0964-5691(98)00058-1.

Zheng, H., \& Zhang, L. (2006). Chinese practices of ecological compensation and payments for ecological and environmental services and its policies in river basins. [Online] Available: http://siteresources.worldbank.org/INTEAPREGTOPENVIRONMENT/Resources/ReportPE SreviewChinesepracticeCAASFinalENFINAL.pdf. (Nov 15, 2012). 


\section{Appendices}

Appendix 1. Institutional arrangements of 13 advanced, small-scale Payments for Ecosystem Services (PES) programs

Country (year; waterbody) ${ }^{\mathrm{a}}$

1 Mexico (2003; Gavilanes R > La Antigua R >> Mexico G $>$ Atlantic $\mathrm{O},<$ Cofre de Perote $\mathrm{V}<$ Sierra Madre Oriental M))

2 Guatemala (2001; Las Escobas R >> Honduras G > Atlantic O)

3 El Salvador (2001; Cara Sucia R >> Pacific O)

4 Honduras (2002; Cumes $\mathrm{R}>$ Otoro $\mathrm{R}>$ Ulua $\mathrm{R}>>$ Intl. donor (SDC), local NGO (JAPOE) Caribbean S)

5 Nicaragua (2003; Los Caballos R $>$ El Gallo R > Negro R Intl. donor (SDC-PASOLAC) >> Fonseca G > Parcific O)

6 Costa Rica (2001; Segundo R > Virilla R > Tarcoles R >> Pacific O)

\section{South America}

$7 \quad$ Colombia (1991; Desbaratado R $>$ Causa R > Magdalena $\mathrm{R}>>$ Caribbean S)

$8 \quad$ Brazil (1989; Piracicaba, Capivari and Jundiai R > Tiete $\mathrm{R}>$ Parana $\mathrm{R}>$ La Plata $\mathrm{R}>>$ Atlantic $\mathrm{O})$

$9 \quad$ Bolivia (2003; Los Negros R $>$ Yapacani R $>$ Grande R $>\quad$ Local NGO (Natura Bolivia) Mamore R > Madeira R > Amazon R >> Pacific O)

10 Ecuador (2001; Palahurco $\mathrm{R}>$ Pisque $\mathrm{R}>$ Chota $\mathrm{R}>$ Mira R > Amazon R >> Alantic O, < Andean M)

\begin{tabular}{ll}
\hline Asia & \\
\hline 11 & China (2000; L Hengjin > Dongyang R > Jinhua R > Lan \\
& $\mathrm{R}>$ Qiantang R $>>$ Hanzhou G > Pacific O) \\
12 & $\begin{array}{l}\text { Indonesia (2000; Besay R (Indonesia, > Tulang Bawang } \\
\end{array}$ \\
$\mathrm{R}>>$ Java S)
\end{tabular}

13 India (1979; L Sukhna $>$ Sukhna $\mathrm{R}>$ Ghaggar $\mathrm{R}>$ Indus $\mathrm{R}>>$ Arabian S; < Sukhna and Kansal $\mathrm{R}<$ Siwalik $\mathrm{M}<$ Himalayas M)
Organizing intermediary ${ }^{\mathrm{b}}$

National gov. (CONAFOR, PSAH), local 01-04 gov. (FIDECOAGUA)

Intl. donors (GTZ, TNC), intl. NGOs 02, 05 (PROARCA, USAID)

Local gov. (Agua, Prosaguas)

06-07 08-09

National gov. (FONAFIFO), local NGO 11-12 (FUNDECOR)

Regional asso. (CVC), local asso. 13-14 (ASOCANA, ASODES)

Regional NPO (PCJ)

$16-17$ Intl. donors (FAO and IAF), local NGO 18-19 (CEDERENA)

ocal gov. (Zhejiang) 20-21

Intl. donors (Ford, DFID), intl. NGO (ICRAF), local NGOs (Watala, Yacili) Intl. donor (Ford), local asso. (HRMS), 24-25 local NGO (CSWCRTI)

a Water courses between payees and payers, downward (">”) into (">>”) seas/oceans, and upward ("<”) to mountains. asso. - association, gov. - government, intl. - international, NGO - non governmental organization, NPO - non profit organization. G - Gulf, L Lake/Reservoir, M - Mountain/Hill, O - Ocean, R - River, S - Sea, year - year of initiation. 'bSOCANA - Association of Sugar Producers, ASODES - Association of Users of the River Desbaratado Watershed, CEDERENA - Ecuadorean Corporation for the Development of Renewable Natural Resources DFID - UK Department for International Development, CONAFOR - Comision Nacional Forestal (National Forestry Commission of Mexico, CSWCRTI - Central Soil and Water Conservation Research and Training Center Institute, CVC - Cauca Valley Corporation, FAO - Food and Agriculture Organization, FIDECOAGUA - Fund for the Promotion, Preservation and Payment for Forest Environmental Services in the Mountain areas of Coatepec in Veracruz, FONAFIFO - National Forestry Fund, FUNDAECO Fundacion para el Ecodesarrollo y la Conservacion, FUNDECOR - Foundation for the Development of the Central Volcanic Range, GTZ German Cooperation Agency, HKM - Community-owned Forest Programme, HRMS - Hill Resource Management Society, IAF Inter-America Foundation, ICRAF - International Centre for Research in Agroforestry, JAPOE - Council for Administration of Water and Sewage Disposal, PASOLAC - Program for Sustainable Agriculture in the Hillsides of Central America, PCJ - Piracicaba, Capivari and Jundiai Rivers Watershed Committees, PROARCA - Regional Environmental Program for Central America, PSAH - Payments for Hydrological Environmental Services Program, SDC - Swiss Agency for Development and Cooperation, TNC - Nature Conservancy, and USAID - US Agency for International Development. ' References: 1 - Blanco and Rojo 2005, 2 - Porras and Neves 2006 , 3 - Scullion et al. 2011, 4 - World Bank 2011, 5 - Corbera et al. 2007, 6 - Herrador and Dimas 2000, 7 - Rosa et al. 2003, 8 - World Bank 2004, 9 - Kosoy et al. 2007, 10 - Perez et al. 2007, 11 - Miranda et al 2003, 12 - Rojas and Aylward 2003, 13 - Echavarria 2002, 14 - Greiber 2009, 15 Da Silva and Folegatti 2009, 16 - Vargas 2004, 17 - Asquith et al. 2008, 18 - Echavarria et al. 2004, 19 - Wunder 2011, 20 - CCICED 2006, 21 - Zheng and Zhang 2006, 22 - Suyanto et al. 2007, 23 - Pasha and Leimona 2011, 24 - Sengupta et al. 2003 , 25 - Agarwal and Narain 2010. 
Appendix 1. (Continued)

\begin{tabular}{|c|c|c|}
\hline & Upstream Payee $^{\mathrm{b}}$ & Conservation services provided \\
\hline \multicolumn{3}{|c|}{ Central America } \\
\hline 1 & Farmers & Reforestation \\
\hline 2 & FUNDAECO (local NGO) & Constructing buffer strip (Cerro San Gil Ecological Reserve) \\
\hline 3 & SalvaNatura (local NGO) & $\begin{array}{l}\text { Park guardians for administration, operation and maintenance (El Imposible } \\
\text { National Park) }\end{array}$ \\
\hline 4 & Farmers & $\begin{array}{l}\text { Organic manure production from coffee pulp processing with earthworm culture } \\
\text { (Montecillos Nature Reserve) }\end{array}$ \\
\hline 5 & Farmers & $\begin{array}{l}\text { Building rows of stone barriers in critical water infiltration points and stone ditches } \\
\text { in creeks with risk of erosion }\end{array}$ \\
\hline 6 & Farmers & $\begin{array}{l}\text { Conservation and natural regeneration and reforestation (Braulio Carrillo National } \\
\text { Park) }\end{array}$ \\
\hline \multicolumn{3}{|c|}{ South America } \\
\hline 7 & Farmers & Reforestation, erosion control, springs and waterways protection \\
\hline 8 & Foresters employed by PCJ & Plantation and maintenance of riparian areas with a reforestation plan \\
\hline 9 & Foresters & Conserving cloud forest \\
\hline 10 & Farmers & Protecting native vegetation with a land management plan \\
\hline \multicolumn{3}{|c|}{ Asia } \\
\hline 11 & Residents & Water diversion project and conservation activities \\
\hline 12 & Farmers in HKM & $\begin{array}{l}\text { Multistrata coffee system (i.e., protecting remaining forests, planting timber and } \\
\text { fruit trees in coffee farms) }\end{array}$ \\
\hline 13 & Farmers & $\begin{array}{l}\text { Protection of forestland from grazing, water harvesting on farmland, construction of } \\
\text { rain water collection dams (Kansal Ki Khol Reserved Forest) }\end{array}$ \\
\hline & Downstream Payer $^{\mathrm{b}}$ & Ecosystem services demanded \\
\hline \multicolumn{3}{|c|}{ Central America } \\
\hline 1 & $\begin{array}{ll}\text { Residents } & \text { represented by } \\
\text { Coatepec } & \text { Municipal Water } \\
\text { Utility } & \end{array}$ & Bundled water and soil quantity and quality \\
\hline 2 & $\begin{array}{lr}\text { Residents } & \text { represented by } \\
\text { Empresa } & \text { Hydroelectric } \\
\text { Company } & \end{array}$ & Water quantity (stable streamflow) \\
\hline 3 & Residents & Bundled water quantity and quality \\
\hline 4 & Residents & Bundled water quantity and quality \\
\hline 5 & $\begin{array}{l}\text { Residents represented by } \\
\text { Municipal } \\
\text { Commission }\end{array}$ & Bundled water quantity and quality \\
\hline 6 & $\begin{array}{llr}\text { Residents } & \text { represented by } \\
\text { Heredia } & \text { Public } \quad \text { Service } \\
\text { Company } & & \\
\end{array}$ & Water quantity (stable streamflow) \\
\hline \multicolumn{3}{|c|}{ South America } \\
\hline 7 & $\begin{array}{l}\text { Farmer members of ASODES } \\
\text { and ASOCANA }\end{array}$ & Bundled water quantity and quality \\
\hline 8 & $\begin{array}{lcc}\text { Residents } & \text { represented } & \text { by } \\
\text { Piracicaba } & \text { Water } & \text { and }\end{array}$ & Water quality (reduced sediment) \\
\hline & Sanitation Utility Company & \\
\hline 9 & Farmers & Water quantity (increased streamflow) \\
\hline 10 & Residents & Water quantity (increased streamflow) \\
\hline \multicolumn{3}{|c|}{ Asia } \\
\hline 11 & Residents & Water quantity (increased streamflow) \\
\hline 12 & $\begin{array}{l}\text { Residents represented by the } \\
\text { central government }\end{array}$ & Bundled water quantity and quality \\
\hline 13 & Residents & Bundled water and soil quantity and quality \\
\hline
\end{tabular}


Appendix 2. Participation of 13 advanced, small-scale PES programs

\begin{tabular}{|c|c|c|c|c|}
\hline \multirow{2}{*}{\multicolumn{2}{|c|}{$\begin{array}{l}\text { Country } \\
\text { (year) }^{\mathrm{a}}\end{array}$}} & \multicolumn{2}{|l|}{ Upstream payees } & \multirow[t]{2}{*}{$\mathrm{d}$} \\
\hline & & Township $^{\text {b }}$ & No. & \\
\hline \multicolumn{5}{|c|}{ Central America } \\
\hline 1 & $\begin{array}{l}\text { Mexico } \\
(2005)\end{array}$ & Coatepec municipality $\left(3^{\text {rd }}\right)$ in Veracruz state $\left(2^{\text {nd }}\right)$ & 110 & 01-04 \\
\hline 2 & $\begin{array}{l}\text { Guatemala } \\
\text { (2002) }\end{array}$ & Livingston municipality $\left(3^{\text {rd }}\right)$ in Izabal department $\left(2^{\text {nd }}\right)$ & 1 & $05-08$ \\
\hline 3 & $\begin{array}{l}\text { El Salvador } \\
(2001)\end{array}$ & $\begin{array}{l}\text { Concepcion de Ataco and Tacuba municipalities }\left(3^{\text {rd }}\right) \text { in Ahuachapan } \\
\text { department }\left(2^{\text {nd }}\right)\end{array}$ & 1 & 09-11 \\
\hline 4 & $\begin{array}{l}\text { Honduras } \\
(2004)\end{array}$ & $\begin{array}{l}\text { Jesus de Otoro community }\left(4^{\text {th }}\right) \text { in Jesus de Otoro municipality }\left(3^{\text {rd }}\right) \text { in } \\
\text { Intibuca department }\left(2^{\text {nd }}\right)\end{array}$ & 4 & $12-14$ \\
\hline 5 & $\begin{array}{l}\text { Nicaragua } \\
(2005)\end{array}$ & San Pedro del Norte municipality $\left(3^{\text {rd }}\right)$ in Chinandega department $\left(2^{\text {nd }}\right)$ & 5 & $15-18$ \\
\hline 6 & $\begin{array}{l}\text { Costa Rica } \\
(2002)\end{array}$ & $\begin{array}{l}\text { Santa Barbara, Barva, San Rafael and San Isidro cantons }\left(3^{\text {rd }}\right) \text { in } \\
\text { Heredia province }\left(2^{\text {nd }}\right) \text { and Moravia canton }\left(3^{\text {rd }}\right) \text { in San Jose province } \\
\left(2^{\text {nd }}\right)\end{array}$ & 21 & $19-21$ \\
\hline \multicolumn{5}{|c|}{ South America } \\
\hline 7 & $\begin{array}{l}\text { Colombia } \\
(2000)\end{array}$ & $\begin{array}{l}\text { Florida province }\left(3^{\text {rd }}\right) \text { in Cauca Valley department }\left(2^{\text {nd }}\right) \text { and Miranda } \\
\text { and Padilla provinces }\left(3^{\text {rd }}\right) \text { in Cauca department }\left(2^{\text {nd }}\right)\end{array}$ & 100 & $22-24$ \\
\hline 8 & $\begin{array}{l}\text { Brazil } \\
(2000)\end{array}$ & $\begin{array}{l}\text { Joanopolis, Piracaia, Nazare Paulista, Mairipora and Analandia } \\
\text { municipalities }\left(3^{\text {rd }}\right) \text { in Sao Paulo state }\left(2^{\text {nd }}\right) \text { and Toledo and } \\
\text { Camanducaia municipalities }\left(3^{\text {rd }}\right) \text { in Minas Gerais state }\left(2^{\text {nd }}\right)\end{array}$ & 137,618 & $25-27$ \\
\hline 9 & $\begin{array}{l}\text { Bolivia } \\
(2007)\end{array}$ & $\begin{array}{l}\text { Santa Rosa community }\left(5^{\text {th }}\right) \text { in Pampagrande municipality }\left(4^{\text {th }}\right) \text { in } \\
\text { Florida province }\left(3^{\text {rd }}\right) \text { in Santa Cruz department }\left(2^{\text {nd }}\right)\end{array}$ & 46 & $28-30$ \\
\hline 10 & $\begin{array}{l}\text { Ecuador } \\
(2001)\end{array}$ & $\begin{array}{l}\text { Mariano Acosta parish }\left(4^{\text {th }}\right) \text { in Pimampiro canton }\left(3^{\text {rd }}\right) \text { in Imbabura } \\
\text { province }\left(2^{\text {nd }}\right)\end{array}$ & 22 & $31-33$ \\
\hline \multicolumn{5}{|c|}{ Asia } \\
\hline 11 & $\begin{array}{l}\text { China } \\
(2000)\end{array}$ & Dongyang county $\left(4^{\text {th }}\right)$ in Jinhua city $\left(3^{\text {rd }}\right)$ in Zhejiang province $\left(2^{\text {nd }}\right)$ & 787,892 & $34-37$ \\
\hline 12 & $\begin{array}{l}\text { Indonesia } \\
(2005)\end{array}$ & $\begin{array}{l}\text { Sumber Jaya district }\left(4^{\text {th }}\right) \text { in West Lampung municipality }\left(3^{\text {rd }}\right) \text { in } \\
\text { Lampung province }\left(2^{\text {nd }}\right)\end{array}$ & 16 & $38-41$ \\
\hline 13 & $\begin{array}{l}\text { India } \\
(1991)\end{array}$ & $\begin{array}{l}\text { Sukhomajri village }\left(6^{\text {th }}\right) \text { in Pinjore town }\left(5^{\text {th }}\right) \text { in Ambala division }\left(4^{\text {th }}\right) \text { in } \\
\text { Panchkula district }\left(3^{\text {rd }}\right) \text { in Haryana state }\left(2^{\text {nd }}\right)\end{array}$ & 97 & $42-46$ \\
\hline
\end{tabular}

${ }^{\mathrm{a}}$ Year - year of transaction. ${ }^{\mathrm{b}}$ Townership - legislative hiercharies in the country system. For example, in PES10, "Mariano Acosta parish $\left(4^{\text {th }}\right)$ in Pimampiro canton $\left(3^{\text {rd }}\right)$ in Imbabura province $\left(2^{\text {nd }}\right)$ " refers that a parish is under a municipality which is under a province which is the second level legislative unit in Ecuador. ' In PES08, the 62 municipalities include: Aguas de SaoPedro, Americana, Amparo, Artur Nogueira, Atibaia, Bom Jesus dos Perdoes, Bragança Paulista, Cabreuva, Campinas, Campo Limpo Paulista, Capivari, Charqueada, Cordeiropolis, Corumbatai, Cosmopolis, Elias Fausto, Holambra, Hortolandia, Indaiatuba, Ipeuna, Iracemapolis, Itapeva, Itatiba, Itupeva, Jaguariuna, Jarinu, Jundiai, Limeira, Louveira, Moji-Mirim, Mombuca, Monte Alegre do Sul, Monte Mor, Morungaba, Nova Odessa, Paulinia, Pedra Bela, Pedreira, Pinhalzinho, , Piracicaba, Rafard, Rio Claro, Rio das Pedras, Saltinho, Salto, Santa Barbara d'Oeste, Santa Gertrudes, Santa Maria da Serra, Santo Antonio de Posse, Sao Pedro, Socorro, Sumare, Tuiuti, Valinhos, Vargem, Varzea Paulista and Vinhedo. The 8 big cities (each with > 200,000 residents) in Sao Paulo state include: Americana, Campinas, Jundia, Limeira, Piracicaba, Rio Claro, Santa Barbara d'Oeste, and Sumare. ${ }^{\mathrm{d}}$ References: 1 - Board of Regents 1975, 2 - Castellon et al. 2008, 3 - Del Angel-Perez et al. 2011, 4 - Mexico INEGI 2011, 5 - Yanez et al. 1999, 6 - Thattai et al. 2003, 7 - UNEP 2005, 8 - Guatemala INE 2002, 9 - USACE 1998b, 10 - El Salvador MINEC 2009, 11 - Kelly 2009, 12 - Mastin 2002,13 - Honduras INE 2006, 14 - Kocsis 2011, 15 - WCS 1998, 16 - Perez et al. 2007, 17 - Nicaragua INIDE 2009, 18 Nicaragua INETER 2012, 19 - Costa Rica IFAM 1985, 20 - Barrantes and Gamez 2007, 21 - Costa Rica INEC 2011,22 Echavarria 2002, 23 - Restrepo et al. 2006, 24 - Colombia DANE 2010, 25 - Formiga-Johnsson and Kemper 2005, 26 - da Silva and Folegatti 2009, 27 - Brazil IBGE 2010, 28 - Herzog et al. 2001, 29 - Bolivia INE 2010, 30 - Bolivia IGM 2012, 31 - USACE 1998a, 32 - Echavarria et al. 2004, 33 - Ecuador INEC 2010, 34 - China NBS 2003, 35 - Liu et al. 2006, 36 Zheng and Zhang 2006, 37 - Fang et al. 2008, 38 - Arifin 2006, 39 - Manik 2008, 40 - Indonesia BPS, 41 - Indonesia KPU 2012, 42 - Singh 2002, 43 - India MWR 2007, 44 - Singh and Tandon 2008, 45 - India Census 2011, and 46 - Lawler 2011. 


\section{Macrothink}

Aquatic Science and Technology

ISSN 2168-9148 2013, Vol. 1, No. 1

Appendix 2. (Continued)

\begin{tabular}{|c|c|c|}
\hline & \multicolumn{2}{|l|}{ Downstream payers } \\
\hline & Township, ${ }^{\mathrm{b}, \mathrm{c}}$ & No. \\
\hline \multicolumn{3}{|c|}{ Central America } \\
\hline 1 & Coatepec city $\left(4^{\text {th }}\right)$ in Coatepec $\left(3^{\text {rd }}\right)$ municipality in Veracruz state $\left(2^{\text {nd }}\right)$ & 79,787 \\
\hline 2 & Puerto Barrios municipality $\left(3^{\text {rd }}\right)$ in Izabal department $\left(2^{\text {nd }}\right)$ & 81,078 \\
\hline 3 & $\begin{array}{l}\text { Cara Sucia canton }\left(4^{\text {th }}\right) \text { in San Francisco Menendez municipality }\left(3^{\text {rd }}\right) \text { in Ahuachapan department } \\
\left(2^{\text {nd }}\right)\end{array}$ & 8,500 \\
\hline 4 & Same & 5,200 \\
\hline 5 & Same & 4,534 \\
\hline 6 & Heredia canton $\left(3^{\text {rd }}\right)$ in Heredia province $\left(2^{\text {nd }}\right)$ & 167,389 \\
\hline \multicolumn{3}{|c|}{ South America } \\
\hline 7 & Same & 1,620 \\
\hline 8 & $\begin{array}{l}62 \text { municipalities }\left(3^{\text {rd }}\right) \text { in Sao Paulo state }\left(2^{\text {nd }}\right) \text { and Extrema municipality in Minas Gerais state } \\
\left(2^{\text {nd }}\right)\end{array}$ & $4,519,681$ \\
\hline 9 & $\begin{array}{l}\text { Los Negros community (5th) in Pampagrande municipality (4th) in Florida province (3rd) in Santa } \\
\text { Cruz department (2nd) }\end{array}$ & 2,970 \\
\hline 10 & Pimampiro parish $\left(4^{\text {th }}\right)$ in Pimampiro canton $\left(3^{\text {rd }}\right)$ in Imbabura province $\left(2^{\text {nd }}\right)$ & 1,350 \\
\hline \multicolumn{3}{|c|}{ Asia } \\
\hline 11 & Yiwu county $\left(4^{\text {th }}\right)$ in Jinhua city $\left(3^{\text {rd }}\right)$ in Zhejiang province $\left(2^{\text {nd }}\right)$ & 668,431 \\
\hline 12 & $\begin{array}{l}\text { Way Kanan, Lampung Utara, Tulangbawang Barat and Tulangbawang municipailities }\left(3^{\text {rd }}\right) \text { in } \\
\text { Lampung province }\left(2^{\text {nd }}\right)\end{array}$ & $1,914,156$ \\
\hline 13 & $\begin{array}{l}\text { Chandigarh city }\left(3^{\text {rd }}\right) \text { as the capital city of both Haryana and Punjab provinces }\left(2^{\text {nd }}\right) \text { and as } \\
\text { Chandigarh union territory }\left(2^{\text {nd }}\right)\end{array}$ & 642,015 \\
\hline
\end{tabular}

\section{Copyright Disclaimer}

Copyright reserved by the author(s).

This article is an open-access article distributed under the terms and conditions of the Creative Commons Attribution license (http://creativecommons.org/licenses/by/3.0/). 